\title{
Effect of Organisational Change on Employee Performance in the Nigerian Deposit Money Banks
}

\author{
Adekunle Olusegun A, $\mathrm{PhD}^{1}$, Ologunagba Oluwakemi ${ }^{2}$, Adekunle Stephen. $\mathrm{K}^{3}$, Olusanya Nasiru Olawale ${ }^{2}$ \\ 1.Department of Business Administration, Gateway Polytechnic Saapade, Ogun State, Nigeria \\ 2. Research Fellow" Department of Business Administration, Babcock University, Ilishan Remo, Ogun State \\ 3.Department of Business Administration and Management, Redeemer's College of Technology and \\ Management, Mowe, Ogun State
}

\begin{abstract}
The position of banking sector in any nation's economy cannot be overemphasized this is because it drives other sectors. Managing employee performance in the face of dynamic changing organizational environment remains critical issue in today's banking sector where the strength of the sector lies in the contribution and commitment of employees. Previous studies on organizational change as it affect employees' performance remained inconclusive. Therefore, this study examined the effect of organizational change on employees' performance in Deposit Money Banks in Lagos State, Nigeria.The study employed a survey research design and a multi-stage sampling technique to select a sample of 623 employees from a total population of 24182 employees in 22 Deposit Money Banks in Lagos, Nigeria. Consequently a structured questionnaire was administered on the respondents while 520 were duly completed and returned representing $83.5 \%$ response rate. Both descriptive and inferential statistics were used to analyzed collected data. Ordered Logistic Regression was used to determine the effects of Organisational change on employee's performance in Deposit Money Banks in the studied area at 95\% confidence level.The study showed average and standard deviation values for organizational change $(-0.0034$, 1.880 and employee's job performance $(2.498,1.317)$, indicating the rate at which these variables deviated from their individual mean values. The results further revealed that organizational change $\left(\beta=-0.628, \mathrm{z}_{\mathrm{c}}=-9.33\right.$, $p=0.067$ had negative effect on employee performance. The study concluded that organizational change significantly affects employee's performance in Deposit Money Banks in Lagos State, Nigeria. It was recommended that the stakeholders in the Nigerian banking industry should communicate changes in advance and also involve employees in the execution of those changes. Organisations should ensure that employees are treated in a just and procedurally manner so as to guarantee employee that the psychological contract between employer and employee remains intact
\end{abstract}

Keywords: Organisational, Change, Banks, Employee, Performance, Deposit, Money

DOI: $10.7176 /$ RHSS/11-20-08

Publication date:October $31^{\text {st }} 2021$

\section{Introduction}

Today's banking in Nigeria has witnessed considerable/significant development owing to its increased performance in the nation's financial sector. The nature of banking industry is different from what obtains in other sector especially manufacturing industries. In banks, the personnel is more integrated in the area of services. Hence, quality employees will continue to determine and predict the success of the organisation in future. Employees who have good sense of responsibility, skill, knowledge and dexterity will accomplish the tasks to fulfill and achieve the organisation's goals and objectives in effective and efficient ways. Various factors like skills, training, motivation, dedication, welfare, management policies, fringe benefits, salary and packages, promotion, communication etc. are necessary to encourage the people to work sincerely and give their optimum best. The significance of employees' performance must be understood by the management and sincere efforts must be put in that direction.

Managing organisational change is one of the most difficult challenging issues in today's ever changing organisation. A successful organisation is one that continually and consistently rises and meets the challenge. These changes in an organisation can help employees to improve their job performance if the organisation implements its changes effectively. The development and survival of the organisation are based on how the organisation is able to navigate the period of change.

In today's dynamic work environment, organisational change is inevitable for every organisation to progress and prosper in ever changing business environment. Organisational change can have different effect on worker's performance depending on how the employees see it as well the nature of the organisation environment or the working situation. It impacts on workers performance in different ways, if well managed, can promote employee performance while reverse is the case if not well handled as expected. It can result to employee becoming apprehensive of their job and invariably not able to put in their best in their job. Thus, the study examines the effect of organizational change on employee job performance in Nigerian Deposit Money Banks. 


\section{Research Objective, Question and Hypothesis}

The broad objective of this study is to examine the effect of organizational change on employee job performance in Nigerian Deposit Money Banks. In view of broad objective of the study, the study intends to answer question; to what extent does organizational change affect employee performance in the Nigerian Deposit Money Banks? The study hypothized that organisational change has no significant effect on the performance of employee in the Nigerian Deposit Money Banks

\section{Significance and Scope of the Study}

This study provides the managements of banking sector in Nigeria with contextualized empirical evidence that would aid better understanding of how to develop and implement policies and practices that would create and sustain better work places and foster engagement of their workforce. It is expected that the findings serve as contributions to the advancement of banking sector in Nigeria. It proffers answers to the questions agitating the minds of managements of organisation as to what to do to mitigate against the challenges of organizational change and employee performance

The study is confined to organizational change and employee performance in Deposit Money Banks in Lagos Nigeria. Organisational change is the independent variable while employee performance which is the dependent variable is measured with task efficiency, work quantity, work quality and creativity. The study covers all the twenty two (22) deposit money banks operating in Lagos, Nigeria.

\section{Conceptual Clarification}

\section{The Concept of Employee Performance}

The performance of an employee is extremely important to the success of every organisation and profitability in this dynamic and ever changing business world. In today's, business environments, it is only employee with the capacity to contribute more than the organisation's expectations and goals that are valued. Employee's job performance has been defined as productivity in terms of quantity and quality expected from each employee. With the ever increasing competition and competitiveness in today's world, all business organisations have tended to recognize the fact that they can only remain afloat and prosper when their employees perform to optimum level. Employee performance is thus seen in terms of the degree to which a worker performs efficiently and effectively to maximum level.

Employee's performance in every organisation is very significant to determine a company's success and profitability. According to Aliyu et. al. ,(2013), a successful organisation values only the employees who are willing to do more than their usual job scope and contribute beyond goals and expectations. Furthermore, employee's performance is also measured in terms of the ability to undertake tasks that require flexiblility and proactiveness as situations demand. Many companies assess their employee's performance on an annual or quarterly basis in order to define certain areas that need improvement because productivity is critical for organisational success. Every organisation is established with certain objectives to achieve, these objectives can only be achieved by utilizing the resources like men, machines, materials and money. All these resources are important but out of these, manpower is the most crucially important. It plays an important role in performing tasks to accomplish the goals. The contribution of employees on job is the most important factor for development and excellence in business.

\section{Concept of Organisational Change}

Organisational change occurs in different ways and thus takes different forms among these are downsizing, merger and acquisition etc. For instance, the effect of organisation downsizing by laying off some workers in an organisation could result in dissatisfaction among other employees. In the same vein, downsizing could create economic and pscychological problems for workers who survive the layoffs. This is because those that survived the downsizing would experience some difficult situations including work overload which ultimately often results in frustration, dissatisfaction and stress. The change process in each organisation is different in each situation because it depends on the nature of the organisations, its business, work culture as well as values, management and leadership style adopted. Change may bring employee satisfaction, joy and advantages to the organisation while it may work negatively in some cases. If organisation change is well planned and implemented, it can influence the task performance, the perception and the performance of employee.

Implementation of changes tends to focus more on the positive changes in work content that results from positive intervention (Hackman and Oldham, 1980). The positive changes are such that it can provide more meaningful patterns of tasks, increase the variety of the task; engender greater employee control over the production process, thereby enabling employee's contribution can receive greater recognition as well as increasing the performance feedback. However, organisational changes also lead to a great deal of uncertainty and stress among employees. When an organisation is facing changes, such changes can create in employee's apprehension, stress and job insecurity. These go a long way in resulting into poor performance and reduction in 
employee`s productivity, delayed in work process satisfaction and commitment towards organisation.

\section{Methodology}

This section discusses the research design adopted, population, sampling method and sampling size, research instrument, nature and description of the questionnaire, modes of data collection and data analysis.

\section{Study Area}

The study was conducted in Lagos, situated in the South West geopolitical Zone of Nigeria. This choice was informed by the fact that all Deposit Money Banks operating in Nigeria transact business there and that over 95 percent of all the Deposit Money Banks operating in the country have their corporate headquarters located in Lagos. (CBN,2018). More so, the largest percentages of all the Deposit Money Banks branches in Nigeria are in Lagos (CBN, 2018) Again, since the banks employees are guided by employment policy, it is believed that whatever is obtainable in Lagos branches cut across every other state of the nation.

\section{Research Design}

Survey method was adopted in carrying out this study. Survey research was applied to this study as a result of the need to generate primary data to achieve the research objective. The survey research design is appropriate because all the variables of the study were observed at a point in time, and research design saves cost. Also, the survey design gives the researcher opportunity to make predictions about the relationships between certain variables.

\section{Population of the Study}

The population of this study made up of all the employees in the 22 Deposit Money Banks operating in Lagos State South-West geopolitical zone in Nigeria with a total population of 24182 as listed by various banks in Nigeria (CBN, 2018).

\section{Sampling Frame}

For the purpose of this study, the working population or sampling frame was limited to all registered Deposit Money Banks, which are recognized by Central Bank of Nigeria (CBN). The reason for the choice of these respondents was to enhance the possibility of generating a well robust primary data from relevant stakeholders.

\section{Sample Size and Sampling Technique}

For simplicity of sample size selection, Bartlett, Kotrlik and Haggins (2001) used the model of Cochran (1977) to construct a table showing the minimum sample size for any given population with an accepted error margin of 0.03 for continuous data and 0.05 for categorical data (Babajide, 2011; Alese, 2017). Using the approach of Bartlett, Kotrlik and Haggins (2001), the sample size chosen to secure representation response for this research study was based on statistical estimation theory considering $95 \%$ confidence level, based on the selection criteria of Bartlett, Kotrlik and Haggins (2001), the sample size of 623 was considered adequate for the study population which is 24,182 .

The sampling technique used for this study is a multi-stage sampling approach. It is a sampling techniques that involves taking of samples in stages using smaller and smaller sampling units at each stage According to Abosede et al (2004), its advantages over other techniques are cost and time effectiveness, and high flexibility.

The first stage involved dividing Lagos State (Choosing Study Area) into three senatorial Districts/Zone. The second stage involved selection of available Deposit Money Banks in Nigeria which are twenty-two (22) in total (Central Bank of Nigeria, 2018) across the three Senatorial Zone in Lagos State using purposive sampling approach. This allowed all banks to be represented in the drawn sample. The final stage makes use of random sampling techniques to select the respondents/participants in each of the banks choosen for the study

\section{Source of Data}

Primary data were collected with the aid of questionnaire from the relevant stakeholders i.e. the staff of the banks on different cadre of employment.

\section{Methods of Data Collection}

This study collected data from primary source. The primary data was collected through the use of a structured questionnaire aimed at gathering information from the respondents. The list of banks and every other information needed for the study were also gathered through various CBN bulletin, industry/trade publication, websites in relation to variables under study and publication from the regulatory agencies in the banking industry.

The research instrument was administered to all selected employees of the Deposit Money Banks in Nigeria with the permission of the branch operation managers of each of the 22 Deposit Money Banks in the various 
offices. The questionnaire was administered to the respondents during the working hour. Each respondent was given a copy of the questionnaire to fill without any form of interference and he/she was at liberty to complete the questionnaire and return

\section{Research Instrument}

A questionnaire labeled "The Effect Orgnisational Change on Employee Performance in the Nigeria Deposit Money Banks was used to draw information from various respondents.

The research instrument was divided into four sections namely, A, B, C, and D. Section A deals with the personal profile where the respondents were asked to provide some background information. Section $\mathrm{B}$ requires the respondents to provide answers to the questions on Organisational Change, Section C deals with Employee Job Performance and Section D is open comment.

The likert type summated rating scale was used in the questionnaire because of its simplicity, ease in being understood by respondents, and its efficacy as a research approach for transforming feelings into a seemingly interval scale which is amenable to statistical analysis (Abosede et al, 2001). In all the five (5) major sections of the research instrument, a five point interval scale was used. The scores was coded 5 for strongly agree, 4 for agree, 3 for indifferent, 2 for disagree and 1 for strongly disagree

\section{Model Specification}

This study adapts the empirical model of Ashby, West and Ames (1989) to investigate the effect of job insecurity $\left(J I S_{i}\right)$ on employee job performance $\left({ }^{E J P_{i}}\right)$ using the Nigerian Deposit Money Banks as case study. The model is stated functionally as:

$$
E J P_{i}=f\left(J I S_{i}\right)
$$

\section{Empirical Model for Hypothesis}

The empirical hypothesis is formulated to evaluate the effects of organizational change on employee job performance in the Nigerian Deposit Money Bank. The model for this hypothesis is stated as:

$$
E J P_{i}=\sigma+\rho O C_{i}+\pi_{1} A G E_{i}+\pi_{2} M S_{i}+\pi_{3} E D U_{i}+\pi_{4} C T_{i}+\pi_{5} L S_{i}+v_{i}
$$

Where: EJP denotes employee job performance measured by task efficiency, work quantity, work quality and professional knowledge and creativity; $O C$ represents organisational change; $A G E$ is age of respondents, $M S$ is marital status, $E D U$ is educational qualification, $C T$ is contract type and $L S$ is length of service; $\sigma, \rho, \pi_{1-5}$ are parameters, $i$ is surveyed bank employees and $v_{i}$ is disturbance term. The equation was first evaluated to test the hypothesis without augmenting the control variables into the employee job performance model. Subsequently, the control variables were incorporated into the model to confirm whether they influence organisational change towards employee performance in the Nigerian Deposit Money Banks.The expected signs and a'priori expectation of equation above are presented in table below

\begin{tabular}{|c|c|c|c|}
\hline $\mathbf{S} / \mathbf{N}$ & Variable & Expected sign & A'priori \\
\hline & EJP $=$ Employee job performance in each respondents & & \\
\hline & \multicolumn{3}{|l|}{ Independent variables } \\
\hline 1. & Organisational change $(\mathrm{OC})$ & + & $\rho>0$ \\
\hline 2. & Age (AGE) & + & $\pi_{1}>0$ \\
\hline 3. & Marital status (MS) & + & $\pi_{2}>0$ \\
\hline 4. & Education qualification (EDU) & + & $\pi_{3}>0$ \\
\hline 5. & Contract type (CT) & + & $\pi_{4}>0$ \\
\hline 6. & Length of service (LS) & + & $\pi_{5}>0$ \\
\hline
\end{tabular}

A'priori Expectation

Note: $\sigma, \rho, \pi_{1-5}$ are parameters

Source: Author's computation.

\section{Methods of Data Analysis}

In this study, statistical (descriptive and inferential) and econometric techniques such as descriptive statistics, Ordered Logistic Regression using STATA version 14.0 was used was used to determine the effect of organizational change and employee job performance respectively. Variables related to the respondents' 
demographic features were analyzed using the descriptive statistical tools.

\section{Results and Discussion}

This phase of the study presents the analysis of data collected on bank employees' views on how organizational change affects employee performance in the Nigerian Deposit Money Banks. Out of the total questionnaires of 623 administered to the targeted respondents, 520 were returned, giving a high response rate at $83.5 \%$.

\section{Hypothesis Testing}

Ho: Organisational change has no significant effect on the performance of an employee in the Nigerian Deposit Money Banks (DMBs).

The Ordered logistic regression results of the effect of organisational change on employee performance in the Nigerian Deposit Money Banks after taking into consideration the demographic and job-related factors. In the table, the coefficients, standard errors in parenthesis and their probability values at $1 \%, 5 \%$ and $10 \%$ are reported. The results showed that the parameters of organisational change are statistically significant in the estimated models of employee performance indicators. In particular, the findings obtained from organisational change index indicate that its variable has negative coefficients for task efficiency, work quantity, work quality, professional knowledge and overall employee task performance. It suggests that employee performance in terms of task efficiency, work quantity, work quality, professional knowledge and creativity and overall task performance are likely to fall as workers are caught unaware of organisational changes. In magnitude terms, the findings suggest that for every one unit increase in organisational changes, the study expects $0.314,0.376,0.740$, 0.478 and 0.628 decreases in the $\log$ odds of task efficiency, work quantity, work quality, professional knowledge and creativity and overall task performance respectively. The negative effects of employees caught unaware of organisation change affect the quality of work delivered by employees.

Ordered Logistic Regression Estimates of Organisational Changes and Employee Performance

\begin{tabular}{|c|c|c|c|c|c|}
\hline \multirow[b]{2}{*}{ Variables } & \multicolumn{5}{|c|}{ Dependent Variable: Employee Performance } \\
\hline & $\begin{array}{c}\text { Task } \\
\text { Efficiency }\end{array}$ & $\begin{array}{c}\text { Work } \\
\text { Quantity }\end{array}$ & $\begin{array}{c}\text { Work } \\
\text { Quality }\end{array}$ & $\begin{array}{c}\text { Professional } \\
\text { Knowledge and } \\
\text { Creativity } \\
\end{array}$ & $\begin{array}{c}\text { Overall } \\
\text { Employee Task } \\
\text { Performance } \\
\end{array}$ \\
\hline \multirow[t]{3}{*}{ Organisational change } & $-0.314 * * *$ & $-0.376^{* * *}$ & $-0.740 * * *$ & $-0.478 * * *$ & $-0.628 * * *$ \\
\hline & $(0.060)$ & $(0.061)$ & $(0.068)$ & $(0.062)$ & $(0.067)$ \\
\hline & {$[-5.26]$} & {$[-6.20]$} & {$[-10.87]$} & {$[-7.76]$} & {$[-9.33]$} \\
\hline \multirow[t]{2}{*}{ Gender: Male } & -0.148 & -0.229 & $-0.382 * *$ & -0.308 & $-0.449 * *$ \\
\hline & $(0.185)$ & $(0.190)$ & $(0.194)$ & $(0.191)$ & $(0.194)$ \\
\hline \multirow[t]{2}{*}{ Age: $30-39$ years } & $0.497 * *$ & -0.093 & -0.239 & 0.052 & 0.358 \\
\hline & $(0.230)$ & $(0.235)$ & $(0.243)$ & $(0.234)$ & $(0.240)$ \\
\hline \multirow[t]{2}{*}{$40-49$ years } & 0.019 & $0.716^{* *}$ & 0.294 & 0.101 & 0.351 \\
\hline & $(0.337)$ & $(0.335)$ & $(0.364)$ & $(0.345)$ & $(0.350)$ \\
\hline \multirow[t]{2}{*}{$50-59$ years } & 0.686 & 0.198 & $-1.692 * *$ & -0.803 & -0.256 \\
\hline & $(0.750)$ & $(0.757)$ & $(0.770)$ & $(0.813)$ & $(0.813)$ \\
\hline \multirow[t]{2}{*}{60 years and above } & -0.526 & 2.041 & 1.881 & -0.408 & $3.786 * *$ \\
\hline & $(1.629)$ & $(1.516)$ & $(1.522)$ & $(1.712)$ & $(1.514)$ \\
\hline \multirow[t]{2}{*}{ Marital status: Married } & -0.097 & $-0.423 * *$ & $-0.574 * *$ & -0.112 & 0.143 \\
\hline & $(0.209)$ & $(0.213)$ & $(0.224)$ & $(0.216)$ & $(0.219)$ \\
\hline \multirow[t]{2}{*}{ Widow } & $-3.614 * * *$ & $-2.833 * * *$ & $2.312 * *$ & -1.614 & $-2.434 * *$ \\
\hline & $(1.056)$ & $(1.053)$ & $(1.134)$ & $(4.322)$ & $(1.023)$ \\
\hline \multirow[t]{2}{*}{ Separated } & 1.400 & 0.692 & 0.627 & 1.333 & 1.296 \\
\hline & $(0.887)$ & $(0.880)$ & $(0.967)$ & $(0.894)$ & $(0.910)$ \\
\hline \multirow[t]{2}{*}{ Education: SSCE } & 0.471 & 0.038 & $0.785^{*}$ & -0.407 & 0.458 \\
\hline & $(0.408)$ & $(0.399)$ & $(0.474)$ & $(0.462)$ & $(0.463)$ \\
\hline \multirow[t]{2}{*}{ NCE/OND } & -0.385 & -0.360 & -0.380 & 0.256 & $-0.466^{*}$ \\
\hline & $(0.251)$ & $(0.268)$ & $(0.276)$ & $(0.268)$ & $(0.268)$ \\
\hline \multirow[t]{2}{*}{ Masters } & -0.040 & -0.032 & -0.218 & -0.013 & 0.086 \\
\hline & $(0.279)$ & $(0.285)$ & $(0.286)$ & $(0.279)$ & $(0.296)$ \\
\hline \multirow[t]{2}{*}{$\mathrm{PhD}$} & -1.302 & -0.390 & -0.938 & -1.034 & -0.046 \\
\hline & (1.140) & (1.061) & (1.121) & $(0.987)$ & $(0.959)$ \\
\hline
\end{tabular}




\begin{tabular}{|c|c|c|c|c|c|}
\hline Contract type: Temporary & $\begin{array}{l}-0.045 \\
(0.193)\end{array}$ & $\begin{array}{l}-0.092 \\
(0.193)\end{array}$ & $\begin{array}{c}-0.471 * * \\
(0.196)\end{array}$ & $\begin{array}{c}0.032 \\
(0.198)\end{array}$ & $\begin{array}{l}-0.144 \\
(0.207)\end{array}$ \\
\hline $\begin{array}{l}\text { Length of Service: } 6-10 \\
\text { years }\end{array}$ & $\begin{array}{c}0.126 \\
(0.224)\end{array}$ & $\begin{array}{c}0.035 \\
(0.227)\end{array}$ & $\begin{array}{c}0.219 \\
(0.235)\end{array}$ & $\begin{array}{l}0.590 * * \\
(0.236)\end{array}$ & $\begin{array}{c}0.228 \\
(0.239)\end{array}$ \\
\hline $11-16$ years & $\begin{array}{l}0.547^{*} \\
(0.314)\end{array}$ & $\begin{array}{c}0.216 \\
(0.321)\end{array}$ & $\begin{array}{l}-0.154 \\
(0.342)\end{array}$ & $\begin{array}{c}0.954 * * * \\
(0.336)\end{array}$ & $\begin{array}{c}0.362 \\
(0.336)\end{array}$ \\
\hline $16-20$ years & $\begin{array}{c}0.534 \\
(0.602)\end{array}$ & $\begin{array}{l}1.491 * * \\
(0.685)\end{array}$ & $\begin{array}{c}0.828 \\
(0.664)\end{array}$ & $\begin{array}{l}1.054 * \\
(0.624)\end{array}$ & $\begin{array}{c}0.842 \\
(0.615)\end{array}$ \\
\hline$>20$ years & $\begin{array}{l}-1.548 \\
(4.483)\end{array}$ & $\begin{array}{l}-1.477 \\
(6.720)\end{array}$ & $\begin{array}{c}1.770 \\
(1.167)\end{array}$ & $\begin{array}{c}0.538 \\
(1.269)\end{array}$ & $\begin{array}{l}-0.247 \\
(1.260)\end{array}$ \\
\hline Constant & $\begin{array}{c}-2.152 * * * \\
(0.281)\end{array}$ & $\begin{array}{c}-2.154 * * * \\
(0.270)\end{array}$ & $\begin{array}{c}-3.349 * * * \\
(0.307)\end{array}$ & $\begin{array}{c}-1.728 * * * \\
(0.264) \\
\end{array}$ & $\begin{array}{c}-1.478 * * * \\
(0.275) \\
\end{array}$ \\
\hline Wald Chi-Square & $63.53 * * *$ & $75.84 * * *$ & $151.6^{* * *}$ & $100.2^{* * *}$ & $124.8 * * *$ \\
\hline Pseudo $\mathrm{R}^{2}$ & 0.601 & 0.598 & 0.623 & 0.597 & 0.652 \\
\hline Log likelihood & -647.49 & -621.32 & -575.80 & -582.11 & -553.00 \\
\hline Observations & 520 & 520 & 520 & 520 & 520 \\
\hline
\end{tabular}

Note: Standard errors and z-score are reported in parentheses () and square bracket [] respectively; *, **, ***: significance levels of $10 \%, 5 \%$, and $1 \%$ respectively.

Source: Author computation from Field Survey

\section{Discussion of Findings}

The parameter estimates of the control variables for demographic and job-related factors are reported in the above table. In the case of gender, the result revealed that gender difference matters in work quality and the overall employee task performance which were found to be negative. Likewise, the contractual terms were found to make no difference in the indicators of employee performance except for work quality which is negative and significant at the conventional level.

The table also reported the performance of employees when the equations were augmented with age, marital status and length of service. Their benchmark categories were respondents within ages of $20-29$ years, people that are single and those with 1-5 years of service correspondingly. The mean performance of employees who are within ages 30 - 39 years are higher about 0.497 for task efficiency, those within 40 - 49 years are higher about 0.716 for work quantity and people between $50-59$ years are higher about 1.680 for work quality while there are no differences among the age brackets for professional knowledge and creativity and overall employee task performance. For respondents' marital status, there are no differences in employee performance for single and married except in work quantity (negative) and work quality (negative), whereas the performance of those separated and widowed are lower across all indicators of employees performance. In regards to length of service, the parameters of people who have been in service for 11-15 years and 16-20 years for task efficiency and work quantity respectively are higher than the benchmark. In the case of professional knowledge and creativity, the parameters of those in service for $6-10,11-15$ and $16-20$ years are higher. However, there no differences in the work quality of employees and the overall performance in regards to the length of service employees have been engaged.

The entry in table above indicates the ordered regression result of the test carried out to examine the effect of organisational change and employee job performance. The result from the table shows that the organisational change has negative and significant effect on employee job performance. Hence, the stated hypothesis that says "Organisational change has no significant effect on the performance of an employee in the Nigerian Deposit Money Banks (DMBs)is hereby rejected while alternative hypothesis is accepted.

The result of the present study is in agreement with few empirical studies which established a relationship between organisational change and employee job performance, such as those of Armstrong-Stassen (2005), Osthus (2007), Probst (2003), Burke (1998), and Ito and Brotheridge (2007) maintained the opinion that Organisational changes can make employees feel that the psychological contract they have with their employer is broken and as such deterred them from putting in their best in term of performance most especially if not get involved in the change. Moreso, downsizing, mergers and restructuring of the organizations usually decrease employee ${ }^{\text {ee }}$ performance (Tavakolia, 2010). However, the study of Rousseau, (1990); Conway and Briner, (2005); Helen Ebongkeng, (2018) revealed that if during the change period, employees are treated in a procedurally just manner (e.g. timely feedback, justification for decision), the psychological contract between employer and employee can remain intact (Koorsgard et al, 2002 cited in Keim et al, 2014).

The result suggests that the banks that strive to give their staff prior information about planned organisational change relating to job security on time before implementation as well as communicates with 
employees regularly when going through change regarding job security would experience greater employee commitment and invariably increase employee job performance compared to when employee are unaware of the change

\section{Summary of Findings, Conclusion and Recommendation}

In testing the formulated hypotheses of the study, items demonstrating organisational change was regressed on employee job performance, based on the result, it shows that organisational change negatively impact the performance of employee of Deposit Money Banks in Nigeria.. Other findings from the study revealed that the parameters of organisational change are statistically significant in the estimated models of employee performance indicators. In particular, the findings obtained from organisational change index indicate that its variable has negative coefficients for task efficiency, work quantity, professional knowledge as well as quality of work and overall employee task performance. It suggests that employee performance in terms of task efficiency, work quantity, professional knowledge and creativity and overall task performance are likely to fall as workers are caught unaware of organisational changes

\section{Conclusion}

This study investigated the effect of organizational change on employee performance in Nigerian Deposit Money Banks. This study, therefore, concluded that organisational change had a negative effect on task efficiency $(T E F)$, work quantity (WQTY), work quality $(W Q L Y)$, professional knowledge and creativity (PKC) which measure employee performance of deposit money banks in Nigeria.

\section{Recommendations}

The stakeholders in the Nigerian banking industry should communicate changes in advance and also involve employees in the execution of those changes. Organisations should ensure that employees are treated in a just and procedurally manner so as to guarantee employee that the psychological contract between employer and employee remains intact

\section{References}

Abosede, A.J, Obasan K.A and Raji B.A. (2001). Research methodology for management science students. Lagos: Mixon Publishers

Alese, O.J. (2017). Strategic management and the development of small and medium enterprises in South-West, Nigeria. A PhD Thesis Submitted to the Department of Business Administration, Faculty of Social and Management Sciences, Olabisi Onabanjo University, Ago-Iwoye, Nigeria.

Aliyu, T.K., Ajani, O.A., and Adisa, A.L. (2013). Declining job security level and workers' performance in selected banks in South Western Nigeria. African Sociological Review. 17(2): 55-70.

Armstrong-Stassen, M (1993). Production workers' reactions to a plant closing: The role of transfer, stress, and support. Anxiety stress and coping: An International Journal, 6(3): 201-214.

Armstrong-Stassen, M. (1994). Coping with transition: A study of layoff survivors. Journal of Organisational Behaviuor, 15, 597-621.

Armstrong-Stassen, M. (2005). Coping with downsizing: A comparison of executive-level and middle managers. International Journal of Stress Management, 12, 117-141.

Ashby, D., West, C.R., and Ames, D. (1989). The ordered logistic regression model in psychiatry- rising prevalence of dementia in old people's homes. Statistics in Medicine, 8, 1317-1326.

Babajide, A. (2011). Effects of Microfinancing on Micro and Small Enterprises (MSEs) in South West, Nigeria. A PhD Thesis submitted to the Department of Banking and Finance, College of Development Studies, Covenant University, Ota, Nigeria.

Bartlett, J.E., Kotrliik, J.K. and Higgins, C.C. (2001). Organisational research: Determining appropriate sample size in survey research. Information Technology, Learning, and Performance Journal, 19(1): 43-50.

Burke, R.J. (1991). Job insecurity in stockbrokers. Journal of Managerial Psychology, 5, 10-16

Burke, R.J. (1998). Job insecurity in recent business school graduates: Antecedents and consequences. International Journal of Stress Management, 5, 113-119.

Burke, R.J., and Cooper, C.L. (2000). The organisation in crisis: Downsizing, restructuring, and privatization. (Eds.). Oxford: Blackwell.

Burke, R.J., and Nelson, D. (1998). Mergers and acquisitions, downsizing, and privatization: A North American perspective. In M. K. Growing, J. D. Kraft, and J. C. Quick (Eds.) The new organisational reality: Downsizing, restructuring, and revitalization. Washington, DC.: American Psychological Association.

Central Bank of Nigeria (2018). List of financial institutions. Accessed from https://www.cbn.gov.ng/Supervision/Inst-DM.asp

Conway, N., and Briner, R.B. (2005). Understanding psychological contracts at work: A critical evaluation of 
theory and research. Oxford: Oxford University Press.

Ebongkeng, H. (2018). Organisational Change and performance- Case study: African financial company. A Published Business Management Postgraduate Thesis Submitted to the Centria University of Applied Science

Hackman, J.R., and Oldham, G.R. (1980). Development of the job diagnostic survey. Journal of Applied Psychology, 60(2):159-170

Hardy, D.J., and Walker, R.J. (2003). Temporary but seeking permanence: a study of New Zealand Temps, Leadership and Organisation Development Journal. 24(3): 141-152.

Harley, B. (1994). The conditions associated with peripheral employment in Australia: An empirical analysis, Employee Relations, 16(8): 19-31.

Hartenian, L., Hadaway, F., and Badovick, G. (2011). Antecedents and consequences of role perceptions: A path analytic approach. Journal of Applied Business Research, 10(2): 40-50.

Hartley, J., and Klandermans, P.G. (1986). Individual and collective responses to job insecurity. in G. Debus and H.-W. Schroiff (Eds.), The Psychology of Work and Organization. 129-136 Amsterdam: Elsevier Science

Hartley, J., Jacobson, D., Klandermans, B., and Van Vuuren, T. (1991). Job insecurity: Coping with jobs at risk. London: Sage.

Heaney, C.A., Israel, B.A., and House, J.S. (1994). Chronic job insecurity among auto-mobile workers: Effects on job satisfaction and health. Social Science and Medicine, 38, 1431-1437.

Ito, J.K., and Brotheridge, C.M. (2007). Exploring the predictors and consequences of job insecurity's components. Journal of Managerial Psychology, 22, 40-64.

Osthus, S. (2007). For better or worse? Workplace changes and the health and well-being of Norwegian workers. Work, Employment and Society. 21, 731-750.

Probst, T.M. (2000). Wedded to the job: Moderating effects of job involvement on the consequences of job insecurity. Journal of Occupational Health Psychology, 5, 63-73.

Probst, T.M. (2002). Layoffs and trade-offs: Production, quality, and safety demands under the threat of job loss. Journal of Occupational Health Psychology, 7, 211- 220.

Probst, T.M. (2003). Exploring employee outcomes of organisational restructuring: A solomon four-group study. Group and Organization Management, 28,416 - 439.

Probst, T.M. (2005). Countering the negative effects of job insecurity through participative decision making: Lessons from The demand control model. Journal of Occupational Health Psychology, 10, 320-329.

Probst, T.M. (2006). Job insecurity and accident under-reporting. Paper Presented at The 21 st annual meeting of The Society for Industrial and Organisational Psychology, Dallas, TX.

Probst, T.M., and Brubaker, T.L. (2001). The effects of job insecurity on employee safety outcomes: Crosssectional and longitudinal explorations. Journal of Occupational Health Psychology, 6, 139-159.

Probst, T.M., Stewart, S.M., Gruys, M.L., and Tierney, B.W. (2007). Productivity, counter productivity and creativity: The ups and downs of job insecurity. Journal of Occupational and Organizational Psychology, 80, 479-497.

Rousseau, D.M and Libuser, C. (1997). Contingent workers in high risk environments. California. Management Review, 39(2): 103-123.

Rousseau, D.M. (1990). New hire perceptions of their own and their employer's obligations: A study of psychological contracts. Journal of Organisational Behavior, 11, 389-400.

Tavakolia, M. (2010). A positive approach to stress, resistance, and organizational. Social and Behavioral Sciences, 5, 1794-1798. 